\title{
Assessing the Introduction of Mobile Banking in Jordan Using Technology Acceptance Model
}

\author{
doi:10.3991/ijim.v4i1.1057 \\ Dr. Mohammed-Issa R. Jaradat and Dr. Naseem M. Twaissi \\ Al Hussein Bin Talal University, Ma'an, Jordan
}

\begin{abstract}
The continuously growing number of mobile users demonstrates that more and more users seek to benefit from the freedom afforded without the need for cables, time and place. The mobility is the driving force behind the new global economy, with mobile banking, banks offer a new revolutionize services and giving their consumers more options than ever before.
\end{abstract}

This study aimed to: (1) Investigate consumers' expectations and attitudes towards mobile banking in Jordan. (2) Identify the problems that organizations and consumers encounter while adopting or using mobile banking. (3) Measure the level of consumers' perceived usefulness (PU), perceived ease of use (PEOU), attitude towards using (ATU), behavioral intention to use (BI), and the actual use (AU) of mobile banking.

Data for this study have been collected using a questionnaire containing 44 questions. Out of 325 questionnaires that have been distributed, 275 are returned $(84.6 \%)$.

As a result of this study it appeared that if consumers have positive Attitudes towards mobile banking, they would rely on it to conduct their banking transactions. This study finds that Jordanian consumers rely on wireless devices (Mobile) for their banking transactions, which leads to the actual use of this new technology, taking into consideration trust as a factor that could affect the success of using mobile banking in Jordan. This study gives quantified indicators about mobile banking and a model that might help in understanding the mobile banking environment in Jordan.

Index Terms-Mobile Banking (MB); Theory of Planned Behavior (TPB); Technology Acceptance Model (TAM); Trust (TMB)

\section{INTRODUCTION}

Wherever they are; at homes or behind offices, people who are using today's major technology are able to collect, send and receive information in minutes; a thing that saves time, money as well as effort. Because of the needs of mobility, the area of wireless device to conduct $\mathrm{M}$ Commerce or M-Business has emerged as a new communication networks and become one of the hottest topics in the last few years.

Mobile phones create a new meaning for business such as mobile financial application (mobile banking, wireless electronic payment systems, micro payments, wireless wallets, and bill payment), mobile shopping, advertising and mobile intrabusiness ( mobile-University (getting student marks or register through mobile devices...etc)).
According to Forrester research group [17], 219 million users will access the Internet via mobile Phone. The use of mobile phones for the implementation of electronic business transactions is additionally boosted by increasingly new technologies, such as wireless application protocol (WAP), bluetooth, and technological developments are changed daily.

Prensky [38], estimated that 1.5 billion mobile phones were used across the world and this is more than three times the number of personal computers (PCs) used, these sophisticated phones have the processing power of a mid1990s PC.

According to Jordan telecommunication market establishment statistics [43], there are 519000 fixed telephone lines and 5314000 mobile lines.

Keen and Mackintosh [27], showed that technological features play an important role in the adoption of mobile value added services. In service use, mobile phones are no longer used as they have typically been used before. Talking and text messaging (SMS) will remain, but extensive service use is expected to grow. These facts, in addition to the more personality of mobile phones over PC's Internet and the range of computer-like functionality offered by top-of-the-range devices, are leading some observers to speculate that many people in the near future will start to see the mobile phone as an alternative to PCs.

Stone [40] claimed that one day, 2 or 3 billion people will have cell phones, and they are not all going to have PCs for that reason the mobile phone will become their digital life.

Mobile banking services or operations such as: account transfers, balance inquiries, bill payments, and stoppayment requests, and some even offer online loan and credit card applications; are still in their immaturity, leaving a great deal of room for development. There is a need, therefore, to understand users' acceptance of mobile banking and to identify the factors affecting their intentions to use mobile banking.

This information can assist developers in the building of mobile banking systems that consumers want to use, or help them to discover why potential users avoid using the existing system.

\section{THEORETICAL BACKGROUND}

In this study, the researchers will investigate the effect of the trust on consumers' attitudes towards mobile banking in Jordan as a new technology by using a well-known model of information technology-adoption and use; it is a technology acceptance model (TAM). Taylor and Todd [42] claimed that theory of reasoned action (TRA), pro- 
posed by Fishbein and Ajzen [15] is a more general theory than technology acceptance model (TAM), proposed by Davis [10]. Therefore, the researchers begin with TRA because TAM is seen as a special case of TRA.

\section{A. Theory of theory of reasoned action (TRA)}

TRA shown in Figure 1, proposed by Fishbein and Ajzen [15], is a well-established model that has been used broadly to predict and to explain human behavior in various domains Chen et al. [8].

The TRA, according to Runyon and Stewart [39], is an effort towards integrating attitude theory, studying group influence on decisions, and research on consumer reference groups. The TRA acknowledges the complexity of consumer behavior, and rather than isolating one behavioral predictor it takes into account all factors influencing consumer behavior. The TRA is especially useful in considering the various factors influencing consumer behavior.

\section{B. Technology Acceptance Model (TAM)}

TAM was initially suggested by Davis [10]. It is one of the most studied and used models in the investigations of user acceptance of information technology. Among the different models that have been proposed the TAM Davis [10], Davis et al. [13].

Agarwal and Prasad [2], claimed that the main reason for popularity of TAM is perhaps its parsimony, as well as its wealth of recent empirical support.

TAM is an information system theory and the main purpose is simply to predict and to explain the user acceptance of information technology. The model addresses the reasons why users either accept or reject the information technology. The revised model by Davis et al. [13], is constructed from: perceived usefulness (PU) is defined by Davis [10], Davis and Cosenza [12], and Davis et al. [13] as the degree to which a person believes that using IT would improve his/her job performance, perceived ease of use (PEOU) is defined by Adams et al. [1] as the degree to which a person believes that using an Information Technology would be free of effort, Attitudes Towards Using (ATU) is defined by Fishbein and Ajzen [15], Fishbein and Ajzen [16], Davis and Cosenza [12], and Yogesh and Dennis [47] as a function of beliefs, positively or unfavorably towards the behavior, behavioral intention $(\mathrm{BI})$ is defined by Fishbein and Ajzen [15], Fishbein and Ajzen [16], and Davis and Cosenza [12] as Behavioral Intentions are our goals, aspirations, and our expected responses to the attitude object, Actual Usage (AU) is defined by Chen et al. [8] as the frequency of using new technology system such as Mobile Banking and the approximate number of times the user uses it in a given period of time and external variables (Trust), as shown in Figure 2.

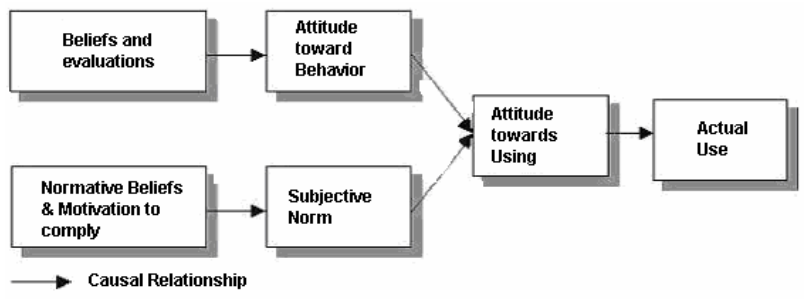

Figure 1. The Theory of Reasoned Action Based on Fishbein and Ajzen [15]

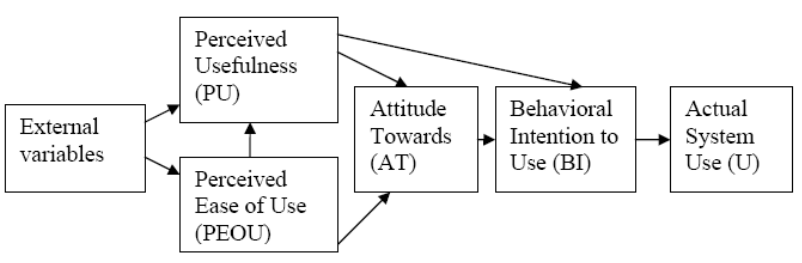

Figure 2. Original Technology Acceptance Model

The idea of TAM is that perceived usefulness and perceived ease of use influence the attitude of the user towards the new information technology then the users' intention to use information technology (either directly or via perceived usefulness), leading to actual use of the new information system.

The interest to the current study is the acceptance of new information technology- mobile banking; thus, a review of prior studies suggested the theoretical foundations of the formulations used in our hypotheses. To this end, this study examines a prevalent theory (i.e., TAM) for investigating individual acceptance in a mobile banking context with external variable trust.

\section{Trust in mobile banking technology}

Lee [29], defined trust as a complex social phenomenon that reflects technological, behavioral, social, psychological, as well as organizational aspects of interactions among various human and non-human agents. All business transactions require an element of trust, especially those conducted in the uncertain environment of commerce.

Gefen et al. [19] claimed that the need for an expansion of the TAM, incorporating additional factors, has already been demonstrated concerning trust.

Gefen et al. [19], suggested that because of the greater ease with which vendors can behave in an opportunistic manner, trust is a major antecedent of participation in Electronic Commerce.

Dahlberg et al. [9] and Grandison and Sloman [20], showed that trust is the key to success for both ECommerce and M-Commerce. Trust is a major facilitator of wireless transactions because of the natural human needs to understand the social surroundings of the virtual environment.

Bhattacherjee [4] and Mukherjee and Nath [35], found that trust and perceived risks have a significant positive influence on commitment.

Bhattacherjee [4] theoretically conceptualized and empirically validated a scale to measure individual trust in online firms. He found that one's willingness to transact with an online firm may be predicted by additional variables above, and beyond trust, such as perceived usefulness and perceived ease of use of such transactions.

Mukherjee and Nath [35], tested a model of trust in India in which "shared value', "communication" and "opportunistic behavior" were antecedents of trust. They concluded that both shared value and communication played a significant positive role on trust and that trust had a significant positive influence on commitment.

Doney and Cannon [14] and Garbarino and Johnson [18], claimed that trust is the essential ingredient for successful long-term business relationships with individuals. 
Viega et al. [46] claimed that business marketers place greater emphasis on building long-term relationships with their individual, trust has assumed a central role.

Gefen et al. [19] introduced trust as another construct of Davis' TAM. An empirical investigation that included (213) subjects confirmed the positive relationship between trust and intended usage of E-Commerce websites. The researchers found that perceived ease of use of the site positively influences the degree of trust in the site.

Dahlberg et al. [9], proposed the application of trust enhanced technology acceptance model in order to investigate user acceptance of Internet applications.

Mathieson et al. [31] and Venkatesh and Davis [45] pointed out that trust in technology acceptance takes two keys trust ingredients: Trust in the company or organization and Trust in electronic channels.

Bunduchi [6], showed that trust is a psychological expectation that a trusted party will not behave opportunistically.

Mayer et al. [32], showed that trust represents the willingness of a party to be vulnerable to the actions of other parties.

McKnight et al. [34], claimed that building customer trust, however, is a costly and time-consuming exercise because trust relationships are formed in the course of long-term interactions between implicated parties.

McKnight et al. [33], McKnight et al. [34], and Koufaris and Hampton-Sosa [28] pointed out that when a new innovative service such as mobile banking is introduced, there is no prior experience to fall back on. The experience or knowledge-based trust that normally develops through iterative interactions may not exist.

Koufaris and Hampton-Sosa [28] showed that a person's initial trust, based on certain sensitive and possibly irrational forces such as cognitive cues, will play an important role in the decision to adopt mobile banking. Initial trust differs from experiential trust in the temporal stage.

McKnight et al. [34], showed that a person initial trust mobile banking is therefore expected to be a function of his/her propensity to trust when there are no experiential elements to factor in.

Mobile Service Provider (MSP) gives a platform for this wireless services i.e. mobile banking, it must be with some critical factors such as coverage, cost, security and privacy.

According to this study, trust is introduced as an external variable of the suggested model. It is hypothesized that the Trust to TAM causal relationships may potentially explain a greater proportion of the variance in user behavioral intentions towards the use of mobile banking. By separating effects of trust from those of perceived risks and security, it is expected that the study will show that trust in the bank and mobile service provider will have some effect on the adoption and use of mobile banking.

\section{RESEARCH MODEL AND HYPOTHESES}

\section{A. Research model}

The present study uses TAM and incorporates variable such as trust as external variable. The research model tested in this study is shown in Figure 3.

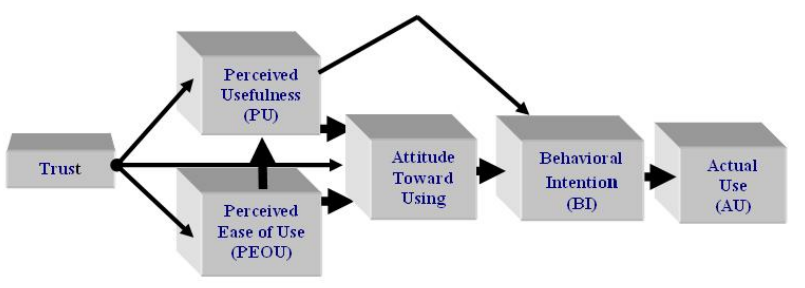

Figure 3. Research model of the study

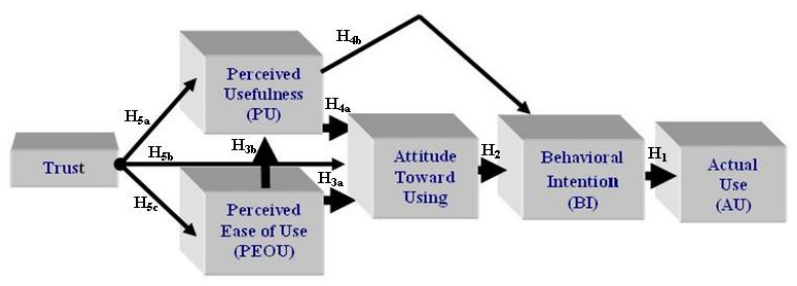

Figure 4. Proposed research model of the study

\section{B. Research hypotheses}

This section presents the hypotheses to be tested and test the effects of the external variable trust and its relationship with a well known model, i.e. technology acceptance model (TAM), as shown in Figure 4 Therefore, Table 1 presents a summary of the interrelationships between hypotheses in the research model.

Most of the studies, reviewed in literature such as Luarn and Lin [30] and Al-Sukkar [3] that use TAM incorporate such variable(s) as an external variable(s); to see if there is an effect they join the external variable(s) with perceived usefulness and perceived ease of use. Therefore, in this study, the researchers exceeds that by incorporate the external variable to see if there is an effect on attitude towards using mobile banking. Based on the literature review and preliminary semi-structure interviews; the analysis suggests that trust has a direct effect on perceived usefulness, perceived ease of use and attitude towards using. Thus, it is hypothesized as in Table 1:

TABLE I.

HYPOTHESES OF THE STUDY

\begin{tabular}{|c|l|c|c|}
\hline & \multicolumn{1}{|c|}{ Hypotheses } & $\begin{array}{c}\text { Inde- } \\
\text { pendent }\end{array}$ & $\begin{array}{c}\text { Depend- } \\
\text { ent }\end{array}$ \\
\hline H1: & $\begin{array}{l}\text { Behavioral intention to use mobile banking } \\
\text { has a direct effect on future actual use of } \\
\text { mobile banking in Jordan. }\end{array}$ & BI & AU \\
\hline H2: & $\begin{array}{l}\text { Attitude towards using mobile banking has } \\
\text { a direct effect on behavioral intention to } \\
\text { use mobile banking in Jordan. }\end{array}$ & ATU & BI \\
\hline H3a: & $\begin{array}{l}\text { Perceived ease of use has a direct effect on } \\
\text { attitude towards using mobile banking in } \\
\text { Jordan. }\end{array}$ & PEOU & ATU \\
\hline H3b: & $\begin{array}{l}\text { Perceived ease of use has a direct effect on } \\
\text { perceived usefulness of using mobile bank- } \\
\text { ing in Jordan. }\end{array}$ & PEOU & PU \\
\hline H4a: & $\begin{array}{l}\text { Perceived usefulness has a direct effect on } \\
\text { attitude towards using mobile banking in } \\
\text { Jordan. }\end{array}$ & PU & ATU \\
\hline H4b: & $\begin{array}{l}\text { Perceived usefulness of mobile banking } \\
\text { has a direct effect on behavioral intention } \\
\text { to use mobile banking in Jordan. }\end{array}$ & PU & BI \\
\hline H5a: & $\begin{array}{l}\text { Trust has a direct effect on perceived use- } \\
\text { fulness to use mobile banking in Jordan. }\end{array}$ & TMB & PU \\
\hline H5b: & $\begin{array}{l}\text { Trust has a direct effect on attitude towards } \\
\text { using mobile banking in Jordan. }\end{array}$ & TMB & ATU \\
\hline H5c: & $\begin{array}{l}\text { Trust has a direct effect on perceived ease } \\
\text { of using mobile banking in Jordan. }\end{array}$ & TMB & PEOU \\
\hline
\end{tabular}




\section{RESEARCH DESIGN AND METHOD}

\section{A. Measuring the constructs}

The researchers use the below instruments to achieve the objectives and answer the questions of this study:

\section{1) Questionnaire:}

The researchers developed a questionnaire based on literature review of the study. The questionnaire consists of multiple items and its organization based on nine groups with a five-point Likert scale ranging from (1) 'strongly disagree' to (5) 'strongly agree' were used.

Measurement items used in this study were adapted from previously validated measures such as [3], [10], [11], [12], [30] and/or were developed on the base of a literature review and/or were derived from thorough consultation with IS/IT experts to ensure their reliability and validity.

The questionnaire was given to a number of referees; the questionnaire statements were modified based on the results of the referee, especially the general information and the translation of the statement from Arabic to English. A pilot test of the measures was conducted on a representative sample of 25 people randomly chosen and some statement of the questionnaire was modified based on the results of the pilot test.

2) Preliminary semi-structured interview:

The researchers use the preliminary semi-structure interviews for both banks and IT managers for the purpose to have an idea about the suitable external variable(s) that effect the adoption and the use of mobile banking in Jordan and to know where the new technology (mobile banking) is.

As a result of the analysis of preliminary semi-structure interviews and reviewed the literature Al-Sukkar [3], Luarn and Lin [30], and Pin and Hsin-Hui [37] related to the domain of this study the researchers determined the suitable external variable (trust).

\section{B. Data collection procedure}

For this study, the researchers will utilize a qualitative analysis (i.e. interview) and a quantitative analysis (survey), the questionnaire was distributed to a representative sample including potential and prospective mobile banking users, all participants were bank consumers selected from universities and companies. In assumption that mobile banking is available and some banks use it to facilitate the financial services for their consumers or plan to use it in near future. Once the data from the survey questionnaires has been gathered, standard editing and coding will be used for the analysis purposes.

The researchers use computer software for the analysis; statistical analyses were performed with SPSS statistical package. Statistical Descriptive was used to find out the respondents' demographic and general characteristics to provide a descriptive profile of the respondents and see if they had any effect in the way they used the mobile banking if needed.

\section{DATA ANALYSIS AND RESUltS}

The data for this research have been collected by using a questionnaire containing about 44 questions. 275 returned questionnaires were received after the follow-up activities from 325. Five participants gave incomplete answers and their results were dropped from the study. This left 270 sets of data for statistical analysis, with an $84.6 \%$ valid return rate.

\section{A. Reliability and Validity}

The researchers use the SPSS package to test the reliability; Cronbach Alpha used to measure internal consistency for state survey and research variables, the results of the reliability test for the measures, as presented in Table 2 suggested that all the measures in this study were reliable. The Alpha coefficients for the measures ranged from 0.6472 to 0.9329 . Hair et al. [21] claimed that a value greater than $0.6(60 \%)$ is regarded as a satisfactory level of internal consistency of measure.

TABLE II.

Alpha Cronbach Test Results of Main Study, No. of CASES=270

\begin{tabular}{|c|c|c|}
\hline Variable & No. of Items & Cronbach's $\boldsymbol{\alpha}$ \\
\hline Trust & 12 & $86.87 \%$ \\
\hline Perceived usefulness & 3 & $93.29 \%$ \\
\hline Perceived ease of use & 4 & $90.00 \%$ \\
\hline Attitude towards use & 3 & $90.80 \%$ \\
\hline Behavioral intention & 3 & $87.37 \%$ \\
\hline Actual use & 2 & $67.53 \%$ \\
\hline Total & 27 & $\mathrm{AVG}=\mathbf{8 5 . 9 8 \%}$ \\
\hline
\end{tabular}

Heneman and Judge [23], defined validity as "the degree to which an instrument measures the attribute or construct it intends to measure". Therefore, the researchers distribute a survey to a number of referees and a group of participants, both of them agree that the questionnaire measure the attribute it intends to measure.

\section{B. Results and discussion}

TABLE III.

ARITHMETIC GRAND MEAN FOR THE SCORES OF RESPONSES FOR ALL STUDY VARIABLES STATEMENTS.

\begin{tabular}{|c|l|c|}
\hline No. & \multicolumn{1}{|c|}{ Variable } & Grand Mean \\
\hline 1 & Trust & 3.47 \\
\hline 2 & Perceived Usefulness & 3.60 \\
\hline 3 & Perceived Easy of Use & 3.61 \\
\hline 4 & attitude towards using & 3.75 \\
\hline 5 & Behavioral Intonation & 3.57 \\
\hline 6 & Actual Use & 3.64 \\
\hline
\end{tabular}

Table 3 illustrated the arithmetic Grand Mean for the scores of responses for all the study variables statements by using SPSS package. When this Grand Mean compared with the 5-points scale from 1 to 5 , it was found that it is greater than the agreement point $(+3)$. Results of the respondent's categorization of the main study (High $>3$, Neutral $=3$, and Low $<3$ ), so, this means it is under the category (High) for each variable. 


\section{Hypotheses Test}

TABLE IV.

AN ILLUSTRATION OF THE RESUlTS OF THE HYPOTHESES OF THE STUDY

\begin{tabular}{|l|c|c|c|c|c|}
\hline & $\begin{array}{c}\text { Independ- } \\
\text { ents }\end{array}$ & $\begin{array}{c}\text { Depend- } \\
\text { ents }\end{array}$ & $\begin{array}{c}\text { Pearson } \\
\text { Correlation }\end{array}$ & $\mathbf{R}^{\mathbf{2}}$ & Result \\
\hline $\mathbf{H}_{\mathbf{1}}:$ & $\mathrm{BI}$ & $\mathrm{AU}$ & 0.732 & 0.536 & Supported \\
\hline $\mathbf{H}_{\mathbf{2}}:$ & ATU & BI & 0.738 & 0.544 & Supported \\
\hline $\mathbf{H}_{3 \mathbf{a}}:$ & PEOU & ATU & 0.436 & 0.190 & Supported \\
\hline $\mathbf{H}_{3 \mathbf{b}}:$ & PEOU & PU & 0.493 & 0.243 & Supported \\
\hline $\mathbf{H}_{4 \mathbf{a}}:$ & PU & ATU & 0.684 & 0.468 & Supported \\
\hline $\mathbf{H}_{\mathbf{4} \mathbf{b}}:$ & PU & BI & 0.603 & 0.363 & Supported \\
\hline $\mathbf{H}_{5 \mathbf{a}}:$ & TMB & PU & 0.493 & 0.243 & Supported \\
\hline $\mathbf{H}_{5 \mathbf{b}}:$ & TMB & ATU & 0.450 & 0.202 & Supported \\
\hline $\mathbf{H}_{5 \mathbf{c}}:$ & TMB & PEOU & 0.318 & 0.101 & Supported \\
\hline
\end{tabular}

** Correlation is significant at the 0.01 level (2-tailed).

\section{Hypothesis 1}

The results of the statistical analysis demonstrated in tables 5 and 6 summarize the results of hypotheses testing, Pearson Correlation coefficient was calculated between behavioral intention as independent variable and Actual Use as dependent variable it was equals to $\mathrm{r}(\mathrm{n}=270)=0.732, \mathrm{p} .=0.01, \mathrm{R}^{2}=0.536$, which means $53.6 \%$ of the variance in Actual Use can be explained by behavioral intention. In order to test the strengths of the relationship between behavioral intention and Actual Use of mobile banking both of them were entered into a regression equation behavioral intention aspect was significantly related to Actual Use. The standardized regression coefficient is equal to 0.732 . And the T-value is equal to 17.606 , which is significant. Therefore, hypothesis 1 has been accepted and the regression equation of the variables is: $\hat{\mathrm{Y}}=1.012+0.734 \mathrm{X}$

This result suggests that the more behavioral intention the potential user has, the more likely he/she starts using the mobile banking.

Tiwari et al. [44] found that the positive shift in the customer perception of Mobile Financial Services (MFS) has turned them into a useful and vital tool to generate, retain, and further strengthen the competitive advantage. With increasing customer mobility, this trend can be expected to gain even higher momentum. In short to medium run, the mobile channel can be expected to become a perhaps indispensable part of the multi-channel strategies in the banking sector.

Irwin et al. [25] showed that the factors that influence the adoption (Actual Use) of mobile banking in South Africa, as a mean of understanding increase the rate of adoption. The factors that are likely to influence adoption include relative advantage, trialability, the customer needs for banking services from a mobile phone, and lower perceptions of risk. The researchers found that Compatibility, Complexity, Mobile phone experience, Facilitating conditions, and Self-efficacy did not show any influence on mobile Banking adoption.

Luarn and Lin [30], they found that M-Banking acceptance model has a higher ability to predict and to explain behavioral intention to use.
Hypothesis 2: The results of the statistical analysis demonstrated in tables 5 and 6 summarize the results of hypotheses testing; Pearson Correlation coefficient was calculated between Attitudes towards Using (ATU) as an independent variable and behavioral intention (BI) as dependent variable. There is a significant positive correlation between attitude towards using and behavioral intention to use mobile banking in Jordan which equals to $\mathrm{r}(\mathrm{n}=270)=$ $0.738, \mathrm{p} .=0.01, \mathrm{R}^{2}=0.544$, which means that $54.4 \%$ of the variance in behavioral intention can be explained by attitude towards using mobile banking in Jordan. Both of them were entered into a regression equation, attitude towards using aspect was significantly related to behavioral intention. The standardized regression coefficient is equal to 0.738 and the T-value is equal to 17.896 , which is significant. Therefore, hypothesis 2 has been accepted. The regression equation of the variables is: $\hat{\mathrm{Y}}=0.851+0.723 \quad \mathrm{X}_{1}$

This result suggests that the more there is an attitude towards using mobile banking the potential user has behavioral intention to use.

Karjaluoto et al. [26], showed that prior experience with computers and technologies and attitudes towards computers influence both attitudes towards online banking and actual behaviors. Their study revealed among these factors that prior computer experience had a significant impact on online banking usage while positive personal banking experience seemed to have an effect on both attitudes and usage and satisfied customers to keep up with their current delivery channel.

\section{Hypothesis 3(a, and b)}

Hypothesis 3a: The results of the statistical analysis demonstrated in tables 5 and 6 summarize the results of hypotheses testing; Pearson Correlation coefficient was calculated between perceived ease of use as independent variable and Attitude towards Use as dependent variable. There is a significant positive correlation between perceived ease of use and Attitude towards using mobile banking in Jordan which equals to $\mathrm{r}(\mathrm{n}=270)=0.436$, $\mathrm{p}$. $=$ $0.01, \mathrm{R}^{2}=0.190$, which means that $19.0 \%$ of the variance in attitude towards using mobile banking can be explained by perceived ease of use. In order to test the strengths of the relationship between perceived ease of use and attitude towards using, both of them were entered into a regression equation, perceived ease of use aspect was significantly related to attitude towards using. The standardized regression coefficient is equal to 0.436 and the T-value is equal to 7.921 , which is significant. Therefore, hypothesis $3 \mathrm{a}$ has been accepted and the regression equation of the variables is: $\hat{Y}=1.942+0.503 \quad \mathrm{X}$

This result suggests that the more mobile banking is Easy to Use the more the potential user(s) has/have attitude towards using it.

Hypothesis 3b: The results of the statistical analysis demonstrated in tables 5 and 6 summarize the results of hypotheses testing; Pearson Correlation coefficient was calculated between perceived ease of use as an independent variable and perceived usefulness of using mobile banking in Jordan as a dependent variable, there is a significant positive correlation between perceived ease of use and perceived usefulness of using mobile banking in Jordan which equals to $\mathrm{r}(\mathrm{n}=270)=0.493, \mathrm{p} .=0.01, \mathrm{R}^{2}=0.243$, which means that $24.3 \%$ of the variance in perceived use- 
fulness of mobile banking can be explained by perceived ease of use. In order to test the strengths of the relationship between perceived ease of use and perceived usefulness, both of them were entered into a regression equation, perceived ease of use aspect was significantly related to perceived usefulness. The standardized regression coefficient is equal to 0.493 and the T-value is equal to 9.271 , which is significant. Therefore, hypothesis $3 \mathrm{~b}$ has been accepted and the regression equation of the variables is: $\hat{\mathrm{Y}}=1.670+0.534 \quad \mathrm{X}$

This result suggests that the more the mobile banking is easy to use the more the potential user(s) has/have a perceived usefulness to use.

Nadim and Noorjahan [36], proposed a conceptual framework that investigates the effects of perceived usefulness, perceived ease of use, and security and privacy on customer adaptation mediated through customer attitude in the context of E-Banking. They found that perceived usefulness, ease of use, security and privacy, and customer Attitude are significantly and positively related to customer adaptation.

Adams et al. [1], found the measurement scales for perceived usefulness and perceived ease of use constructs valid and reliable.

Chavidi and Mulabagula [7] found the perceived barriers for the adoption of Mobile Internet Banking services by the account holders of different banks in Klang Valley of Malaysia. They found that the ease of access (PEOU) to relevant information or service is the most important feature in Mobile Internet Banking.

\section{Hypothesis 4(a, and b)}

Hypothesis 4a: The results of the statistical analysis demonstrated in tables 5 and 6 summarize the results of hypotheses testing; Pearson Correlation coefficient was calculated between perceived usefulness as an independent variable and attitude towards using mobile banking in Jordan as a dependent variable, there is a significant positive correlation between perceived usefulness and attitude towards using mobile banking in Jordan which equals to $\mathrm{r}(\mathrm{n}=270)=0.684, \mathrm{p} .=0.01, \mathrm{R}^{2}=0.468$, which means that $46.8 \%$ of the variance in attitude towards using mobile banking in Jordan can be explained by perceived usefulness. In order to test the strengths of the relationship between perceived usefulness and attitude towards using, both of them were entered into a regression equation, perceived usefulness aspect was significantly related to attitude towards using. The standardized regression coefficient is equal to 0.684 and the T-value is equal to 15.346 which is significant. Therefore, hypothesis $4 \mathrm{a}$ has been accepted and the regression equation of the variables is: $\hat{\mathrm{Y}}=1.135+0.729 \mathrm{X}$

This result suggests that the more the perceived usefulness of a particular system would enhance his or her job performance (improve performance in conducting banking transactions via mobile) the more likely is that he/she has an attitude towards using mobile banking in Jordan.

Most studies have found that PU has a stronger association with attitude, BI, and usage behavior than does PEOU (e.g., Davis [10], Davis and Cosenza [12], Henderson and Divett [22], Subramanian [41]). However, some Studies have found an opposite result: that PEOU is more influential than PU (e.g., Adams et al. [1], Brown et al. [5], and Igbaria et al. [24]), or that the influence is relatively similar Agarwal and Prasad [2].

In this study, the researchers agree with the first assumption that PU has a stronger association with Attitude, BI, and usage Behavior than does PEOU; because of the Pearson Correlation coefficient between PU and ATU is 0.684 and the $\mathrm{R}^{2}=0.468$ which means that $46.8 \%$ of the variance in attitude towards using mobile banking in Jordan can be explained by perceived usefulness. But the Pearson Correlation coefficient between PEOU and ATU is 0.436 and the $\mathrm{R}^{2}=0.190$ which means that $19.0 \%$ of the variance in Attitude towards using mobile banking can be explained by perceived ease of use.

Hypothesis 4b: The results of the statistical analysis demonstrated in tables 5 and 6 summarize the results of hypotheses testing; Pearson Correlation coefficient was calculated between perceived usefulness as an independent variable and behavioral intention to use mobile banking in Jordan as a dependent variable, there is a significant positive correlation between perceived usefulness and behavioral intention to use mobile banking in Jordan which equals to $\mathrm{r}(\mathrm{n}=270)=0.603, \mathrm{p} .=0.01, \mathrm{R}^{2}=0.363$, which means that $36.3 \%$ of the variance in behavioral intention to use mobile banking in Jordan can be explained by perceived usefulness. In order to test the strengths of the relationship between perceived usefulness and behavioral intention, both of them were entered into a regression equation. The standardized regression coefficient is equal to 0.603 and the T-value is equal to 12.363 , which is significant. Therefore, hypothesis $4 \mathrm{~b}$ has been accepted and the regression equation of the variables is: $\hat{\mathrm{Y}}=1.304$

This result suggests that the more perceived usefulness of a particular system would enhance his/her job performance (improve performance in conducting banking transactions via mobile), the more likely is that he/she has a behavioral intention to use mobile banking in Jordan.

Nadim and Noorjahan [36], proposed a conceptual framework that investigates the effects of perceived usefulness, ease of use, and security and privacy on customer adaptation mediated through customer attitude in the context of E-Banking. They found that perceived usefulness, ease of use, security and privacy, and customer Attitude are significantly and positively related to customer adaptation.

\section{Hypothesis 6(a, b, and c)}

Hypothesis 6a: The results of the statistical analysis demonstrated in tables 5 and 6 summarize the results of hypotheses testing; Pearson Correlation coefficient was calculated between Trust as an independent variable and perceived usefulness to use mobile banking in Jordan as a dependent variable, there is a significant positive correlation between Trust and perceived usefulness to use mobile banking in Jordan which equals to $\mathrm{r}(\mathrm{n}=270)=0.493$, $\mathrm{p}$. $=$ $0.01, \mathrm{R}^{2}=0.243$, which means that $24.3 \%$ of the variance in perceived usefulness to use mobile banking in Jordan can be explained by Trust. In order to test the strengths of the relationship between Trust and perceived usefulness, both of them were entered into a regression equation. Trust aspect was significantly related to perceived usefulness. The standardized regression coefficient is equal to 0.493 and the T-value is equal to 9.280 which is significant. Therefore, hypothesis $6 a$ has been accepted and the 
regression equation of the variables is: $\hat{\mathrm{Y}}=1.147+0.706 \quad \mathrm{X}$,

This result suggests that the more Trust in mobile banking does a particular user has, the more likely is that he/she has a perceived usefulness (improve performance in conducting banking transactions via mobile) to use.

Hypothesis 6b: The results of the statistical analysis demonstrated in tables 5 and 6 summarize the results of hypotheses testing; Pearson Correlation coefficient was calculated between Trust as an independent variable and attitude towards using mobile banking in Jordan as a dependent variable, there is a significant positive correlation between Trust and attitude towards using mobile banking in Jordan which equals to $\mathrm{r}(\mathrm{n}=270)=0.450, \mathrm{p} .=0.01$, $\mathrm{R}^{2}=0.202$, which means that $20.2 \%$ of the variance in attitude towards using mobile banking in Jordan can be explained by Trust. In order to test the strengths of the relationship between Trust and attitude towards using, both of them were entered into a regression equation. Trust aspect was significantly related to attitude towards using. The standardized regression coefficient is equal to 0.450 and the T-value is equal to 8.245 which is significant. Therefore, hypothesis $6 \mathrm{~b}$ has been accepted and the regression equation of the variables is: $\hat{Y}=1.375+0.686 \quad X_{1}$

This result suggests that the more Trust in mobile banking does a particular user has the more likely is that he/she has an Attitude towards using it.

Hypothesis 6c: The results of the statistical analysis demonstrated in tables 5 and 6 summarize the results of hypotheses testing; Pearson Correlation coefficient was calculated between Trust as independent variable and Perceived Ease of Using mobile banking in Jordan as dependent variable, there is a significant positive correlation between Trust and Perceived Ease of Using mobile banking in Jordan which equals to $\mathrm{r}(\mathrm{n}=270)=0.318, \mathrm{p} .=0.01$, $\mathrm{R}^{2}=0.101$, which means $10.1 \%$ of the variance in Perceived Ease of Using mobile banking in Jordan can be explained by Trust. In order to test the strengths of the relationship between Trust and Perceived Ease of Using, both of them were entered into a regression equation, the perceived ease of use as dependent variable. The standardized regression coefficient is equal to 0.318 and the $\mathrm{T}$ value equal to 5.482 which is significant. Therefore, hypothesis $6 \mathrm{c}$ has been accepted and the regression equation of the variables is: $\hat{Y}=2.151+0.419 \quad \mathrm{X}_{1}$

This result suggests that the more Trust in mobile banking does a particular user has the more likely is that he/she believes that it is easy to use.

Gefen et al. [19] suggested that trust is a significant antecedent of participation in Online Commerce, and introduced trust as another construct of Davis' TAM.

Bhattacherjee [4] and Mukherjee and Nath [35], found that trust and perceived risks have a significant positive influence on commitment.

Mukherjee and Nath [35], they concluded that both shared value and communication played a significant positive role on trust and that trust had a significant positive influence on commitment.

Dahlberg et al. [9] and Grandison and Sloman [20], showed that trust is the key to success for both ECommerce and M-Commerce. Trust is a major facilitator of wireless transactions because of the natural human needs to understand the social surroundings of the virtual environment.

Zikmund [48] found that TAM can predict consumer intention to use mobile banking. Specifically, trust-based constructs, perceived credibility has a significant effect on user's Attitude towards using mobile banking.

Those results are agreed with our study. Therefore, the trust is important to adopt and use a new technology such as mobile banking and it is significant for all the hypotheses (H6a, H6b, and H6c).

\section{CONCLUSIONS}

The purpose of this article has been to explore factors that influence the intention of users to adopt and use mobile banking. For this purpose a simple model based on technology acceptance model was developed and measured with external variable (Trust) based on semi-structure interviews and literature review. The results suggest that: First, the researchers find that there is a direct effect between Trust and attitude towards using, perceived usefulness, and perceived ease of use towards mobile banking in Jordan. Second, the researchers find that there is a direct effect between perceived usefulness and both attitude towards using and behavioral intention to use mobile banking in Jordan. Third, the researchers find that there is a direct effect between perceived ease of use and both attitude towards using and perceived usefulness towards using mobile banking in Jordan. Forth, the researchers find that there is a direct effect between attitude towards using and behavioral intention to use mobile banking in Jordan. Finally, as an ultimate goal, the researchers find that there is a direct effect between behavioral intention and Actual Use towards using mobile banking in Jordan with 53.6\% of variance that can be explained by behavioral intention.

This study finds out that consumers have an attitudes to rely on mobile banking to conduct their banking transaction, taking into consideration the factors that could affect the success of using mobile banking in Jordan

\section{REFERENCES}

[1] Adams D., Nelson. R., and Todd P. (1992). "Perceived usefulness, Ease of Use, and Usage of Information technology: A Replication". MIS Quarterly, Vol. 16, No. 2, pp. 227-247. (doi:10.2307/ 249577)

[2] Agarwal R., and Prasad J. (1999). "Are individual differences germane to the acceptance of new information technologies? ". Decision Sciences, Vol. 30, No. 2, pp. 361-391. (doi:10.1111/ j.1540-5915.1999.tb01614.x)

[3] Al-Sukkar A. (2005). "The Application of Information System in the Jordanian Banking Sector: A study of the Acceptance of the Internet". PhD Thesis. New South Wales, Australia, University of Wollongong.

[4] Bhattacherjee A. (2002). "Individual trust in online firms: scale development and initial test". Journal of Management Information Systems, Vol. 19, No. 1, pp. 211-241.

[5] Brown S., Massey A., and Burkman J. (2002). "Do I really have to? User acceptance of mandated technology". European Journal of Information Systems, Vol. 11, pp. 283-295. (doi:10.1057/ palgrave.ejis.3000438)

[6] Bunduchi R. (2005). "Business relationships in Internet based electronic markets: the role of goodwill trust and transaction costs". Information Systems Journal, Vol. 15, No. 4, pp. 321-341. (doi:10.1111/j.1365-2575.2005.00199.x)

[7] Chavidi N., and Mulabagula G. (2004). "Barriers to mobile Internet Banking services adoption: an empirical study in Klang valley of Malaysia". The Internet Business Review, Issue No. 1.

[8] Chen L., Gillenson M., and Sherrell D. (2002). "Enticing online consumers: an extended technology acceptance perspective". Information and Management, Vol. 39, No. 8, pp. 705- 719. 
[9] Dahlberg T., Mallat N., and Öörni A. (2003). "Trust enhanced Technology Acceptance Model - Consumer acceptance of mobile payment solutions". Proceedings of the Stockholm Mobility Roundtable, Stockholm.

[10] Davis F. (1989). "perceived usefulness, perceived ease of use, and User Acceptance of Information Technology". MIS Quarterly, Vol. 13, No. 3, pp. 318-339. (doi:10.2307/249008)

[11] Davis F., and Venkatesh D. (1995). "Measuring user acceptance of emerging information technologies: An assessment of possible method biases". In $28^{\text {th }}$ Annual Hawaii International Conference on System Sciences, Hawaii, IEEE computer society press, Los Alamitos, Calif, pp. 729-736.

[12] Davis D., and Cosenza R. (1993). "Business research for decision making". California: Wadsworth Publishing Company.

[13] Davis F., Bagozzi R., and Warshaw P. (1989). "User Acceptance of Computer Technology: A Comparison of Two Theoretical Models". Management Science, Vol. 35, No. 8, pp. 982-1003. (doi:10.1287/mnsc.35.8.982)

[14] Doney P., and Cannon J. (1997). "An Examination of the Nature of Trust in Buyer-Seller Relationships". Journal of Marketing, Vol. 61, No. 2, pp 35-51. (doi:10.2307/1251829)

[15] Fishbein M., and Ajzen I. (1975). "Belief, Attitude, Intentions and Behavior: An Introduction to Theory and Research". Boston: Addison-Wesley.

[16] Fishbein M., and Ajzen I. (1979). "A Theory of Reason Action: Some application sand Implications". In Nebraska Symposium on Motivation, H. Howe and Page (edn). University of Nebraska Press, Lincoln, NB, pp. 65-116.

[17] Forrester Research group [Xonline] www.forrester.com, access date on 2007.

[18] Garbarino E., and Johnson M. (1999). "The Different Roles of Satisfaction, Trust, and Commitment in Consumer Relationships". Journal of Marketing, Vol. 63, No. 2, pp. 70-87. (doi:10.2307/ $\underline{1251946)}$

[19] Gefen D., Karahanna E., and Straub D. (2003). "Trust and TAM in online shopping: An integrated model". MIS Quarterly, Vol. 27, No. 1, pp. 51-90.

[20] Grandison T., and Sloman M. (2000). "A Survey of trust in Internet applications". IEEE Communications Surveys, Vol. 3, No. 4 pp 2-16. (doi:10.1109/COMST.2000.5340804)

[21] Hair J., Babin B., Money A., and Samouel P. (2003). "Essentials of Business Research Methods". Lehigh Publishing, Inc.

[22] Henderson R., and Divett M. (2003). "Perceived usefulness. Ease of use and electronic supermarket use". International Journal of Human-Computer studies, Vol. 59, No. 3, pp. 383-395. (doi:10. 1016/S1071-5819(03)00079-X)

[23] Heneman H., and Judge T. (2003). "Staffing Organization". $4^{\text {th }}$ edn. McGraw-Hill, New York.

[24] Igbaria M., and Tan M. (1997). "The consequences of information technology acceptance on subsequent individual performance". Information and Management, Vol. 32, No. 3, pp. 113-121.

[25] Irwin B., Zaheeda C., Douglas D., and Shaun S. (2003). "Cell phone banking: predictors of adoption in South Africa-an exploratory study". International Journal of Information Management, Vol. 23, No. 5, pp. 381-394. (doi:10.1016/S0268-4012(03)000653)

[26] Karjaluoto H., Mattila M., and Pento T. (2002). "Factors underlying attitude formation towards online banking in Finland". International Journal of Banking Marketing, Vol. 20 No. 6, pp. 261-272. (doi:10.1108/02652320210446724)

[27] Keen P., and Mackintosh R. (2001). "The Freedom Economy: Gaining the M-Commerce Edge in the Era of the Wireless Internet". New York, Osborne/McGraw-Hill.

[28] Koufaris M., and Hampton-Sosa W. (2004). "The development of initial trust in an online company by new customers". Information and Management, Vol. 41, No. 3, pp. 377- 397 (doi:10.1016/ j.im.2003.08.004)

[29] Lee H. (1998). "Do Electronic Marketplaces Lower the Price of Goods?". Communications of the ACM, Vol. 41, No. 1, pp. 73-80. (doi:10.1145/268092.268122)

[30] Luarn P., and Lin H. (2005). "Toward an understanding of the behavioral intention to use mobile banking". Computers in Human Behavior, Vol. 21, No. 6, pp. 873-891. (doi:10.1016/j.chb.200 4.03.003)

[31] Mathieson K., Peacock E., and Chin W. (2001). "Extending the technology acceptance model: The influence of perceived user resources". DATA BASE for Advances in Information Systems, Vol. 32, No. 3, pp. 86-112.
[32] Mayer R., Davis J., and Shoorman F. (1995). "An integrative model of organization trust". Academy of Management Review, Vol. 20, No. 3, pp. 709-734. (doi:10.2307/258792)

[33] McKnight D., Choudhury V., and Kacmar C. (2002). "Developing and validating trust measures for E-Commerce: an integrative typology". Information Systems Research, Vol. 13, No. 3, pp. 334359. (doi:10.1287/isre.13.3.334.81)

[34] McKnight D., Cummings L., and Chervany N. (1998). "Initial Trust Formation in New Organizational Relationships". Academy of Management Review, Vol. 23, No. 3, pp. 473-490. (doi:10.2307/259290)

[35] Mukherjee A., and Nath P. (2003). "A model of trust in online relationship banking". International Journal of Bank Marketing, Vol. 21, No. 1, pp. 5-15. (doi:10.1108/02652320310457767)

[36] Nadim J., and Noorjahan B. (2008). "The role of perceived usefulness, perceived ease of use, security and privacy, and customer attitude to engender customer adaptation in the context of electronic banking". African Journal of Business Management, Vol. 2, No. 1, pp. 32-40.

[37] Pin L., and Hsin-Hui L. (2004). "Toward an understanding of the behavioral intention to use mobile banking". Computers in Human Behavior, Vol. 21, No. 6, pp. 873-891.

[38] Prensky M. (2004). "What can you learn from a cell phone? Almost anything!", Journal of Online edn., Retrieved February 17, 2007 from (http://www.elearningsource .info)

[39] Runyon K., and Stewart D. (1987). "Consumer behavior and the practice of marketing". Columbus, Ohio: Merrill Publishing Company.

[40] Stone B. (2004). "Your next computer". Newsweek, access date June 7. (http://www.msnbc.msn.com/id/5092826/site/newsweek), access date on 2008

[41] Subramanian G. (1994). "A Replication of perceived usefulness and perceived ease of use Measurement". Decision Sciences, Vol. 25, No. 5, pp. 863-8 74 .

[42] Taylor S., and Todd P. (1995). "Understanding Information Technology Usage: A Test of Competing Models". Information Systems Research, Vol. 6, No. 2, pp. 143-176. (doi:10.1287/isre. 6.2.144)

[43] Telecommunication Regulatory Commission Jordan, access date on 2008, (http://www.trc.gov.jo/index.php?option= com content\& task=view\&id=337\&Itemid=507\&lang=english), access date on 2009.

[44] Tiwari R., Buse S and Herstatt C. (2007) "Mobile Services in Banking Sector: The Role of Innovative Business Solutions in Generating Competitive Advantage". in Proceedings of the International Research Conference on Quality, Innovation and Knowledge Management, New Delhi, pp. 886-894.

[45] Venkatesh V., and Davis F. (2000). "A Theoretical Extension of the Technology Acceptance Model: Four Longitudinal Field Studies". Management Science, Vol. 46 No. 2, pp. 186-204. (doi:10.1287/mnsc.46.2.186.11926)

[46] Viega J., Kohno T., and Potter B. (2001). "Trust (and mistrust) in secure applications". Communications of the ACM, Vol. 44, No. 2, pp. 31-36. (doi:10.1145/359205.359223)

[47] Yogesh M., and Dennis F. (1999). "Extending the Technology Acceptance Model to Account for Social Influence: Theoretical Bases and Empirical Validation". Hawaii International Conference on System Sciences, IEEE, Thirty-Second Annual -Vol 1, pp. 1006.

[48] Zikmund W. (2003). "Business research methods". ( $7^{\text {th }}$ edn) Australia, Thomson South Western.

\section{AUTHORS}

Dr. Mohammed-Issa Riad Mousa Jaradat, is with the Department of Business Administration / Management Information Systems in College of Business Administration and Economics - Al Hussein Bin Talal University, Ma'an, Jordan (e-mail: mi_jaradat@ahu.edu.jo).

Dr. Naseem Mohammad Twaissi, is with the Department of Business Administration in College of Business Administration and Economics - Al Hussein Bin Talal University, Ma'an, Jordan (e-mail: ntwaissi@ahu.edu.jo).

Submitted 09 September 2009. Published as resubmitted by the authors on December, 2, 2009. 